DOI: 10.31866/2616-7581.4.1.2021.233334

UDC 782.1:781.7]:78.071.1(560)Saygun

\title{
ANALYSIS OF THE OPERA KEREM BY AKHMET ADNAN SAYGUN
}

\author{
Aysel Asadova
}

Doctoral Student; ORCID: 0000-0001-8183-3191; e-mail: aysel_asadova@inbox.ru

Baku Music Academy named after U. Hajibeyli, Baku, Azerbaijan

\section{Abstract}

The article analyzes the musical language of the opera Kerem by A. Adnan Saygun. Ahmet Adnan Saygun was born during the Ottoman period and lived in the newly created Republic of Turkey. Saygun is one of the founders of the Turkish School of Composing, as well as one of the founders of the Turkish Five. The composer paid great attention to folk art and national values. You can always see folk music and folklore in his works.

The purpose of the research is to analyze Sufi motives in the scenes of the opera. Mainly, the attention is paid to musical drama and harmonic aspects of the opera, which directly reflect Turkish folklore and musical culture in general.

The research methodology lies in solving a scientific and theoretical problem. A number of theoretical and analytical methods have been applied, highlighting the principle of using a literary text in musical scenes that contain phrases that reflect "reunification with the Creator" in Sufism. The use of characteristic rhythmic patterns in mystical scenes, when searching for information, the methods of the axiological concept of culture were used, which made it possible to highlight the characteristic features of Turkish music.

The scientific novelty of the research lies in the fact that for the first time the reflection of religious characteristics based on folk music, in particular, based on modal structures and maqams, analysis of the mystical motives of the opera, in combination with modern musical techniques is considered.

Conclusions. Saigun's opera Kerem is one of the rare works based on Sufi philosophy. A clear reflection of the main thought of Sufi philosophy was noted in Kerem, according to which the suffering of the seeker of truth is marked by a return to it. The way of light is the way of Allah. The composer, to show the unique colour and character of Anatolia, the life and customs of people, used the fret and rhythmic structure characteristic of Turkish music. As a result of the study, we see how in Kerem the author enthusiastically and passionately works on national values in all aspects of the opera.

Keywords: opera; modal structure; mystic; polytonal style; basics of folk music

\section{Introduction}

Kerem Opera, composed by Ahmet Adnan Saygun, is the first Turkish opera written in the great opera genre. It is also a lyrical mystical drama. Love is Kerem's stron- 
gest support in the war against destiny. For centuries, the belief that reaching the level of God is possible only through love has followed each other since Plato. Turkish-Islamic thinkers believed that the connection between existence and God, their desire to reach Him, their destruction in Him, and their ideas would be realized through love. Kerem is a product of this Sufi philosophy (Gun, 1991).

Kerem Opera is similar to Yunus Emre Oratorio in terms of orchestral use and harmony. Therefore, Gazimihal's comments are a natural result. The choir was widely used in the work. The use of this great choir is a reflection of the composer's personal choice. This is a clear indication of the importance Saygun attaches to this issue, which he began to work on in the choir upon his return to his country after the education in Paris (Altar, 2001, p. 233).

"One of the most important features of Kerem's opera is that the opera is based on folklore, folk music, and oral traditions. Folklore is neither a model nor a repertoire for citation. In Kerem's opera, every folkloric and traditional element is universal, designed and recreated with great skill and enthusiasm following the theories and rules of world music. Living traditions; can be updated at any time. Societies that have lost the ability to regenerate will have neither traditional art nor folklore" (Refiğ, 2012, p. 15).

\section{Main research material}

Saygun creates a musical language that matches the libretto of the work. The work was a great success. Indeed, the composer took into account the principle of sensitive and clear understanding of words in the applications of this genre, and to ensure its unification, he attached great importance to the principle of evaluating Turkish as a musical language without losing its features. The composer approached the choir parts of the opera with the same sensitivity but used a simple rhythmic structure.

As a general structure of the work:

1) pentatonic; 2) lad-point; 3) use of tonality; 4) polytonal use (two different tones overlap); 5) melodies created by the author in the style of folk songs; 6 ) use of folk music or hymns.

The first two cells in the work begin with the use of two distant axis chords, the FisDur chord below, and the polychoric arpeggio above the C Dur chords above (known as "Petrushka chord", first used by Stravinsky), then continue pentatonic.

Saygun, as in many of his works, used only the music he created in the form of folk music in the structure of this opera. One of the best examples of this is the playful melody in number 5 .

For example, at the beginning of the melody, Saygun exhibits the melody he composed in a polymodal structure (the left hand was used on the piano (is $\mathrm{C}$ ), the right hand is on the Cis curtain, the F-shaped series). This use is known in Turkish music as a playful curtain (to be used with different variations depending on whether one or more of the curtains rises and falls). The part, which varies in size from five, eight, nine to eight, is heard as Husseini on the sound of the Fis. The political structure continues in progressive dimensions after the pattern. The example of halay in the eighth issue is an excerpt from the folk music of the Bayburt and Erzincan regions known as 
Mrs Bari. Saygun used a simple melody to a harp. In the thirteenth part, the Halay Yeldirmesi (the fastest part of the halay) is used in the order of the Armored Hijaz status on the A sound.
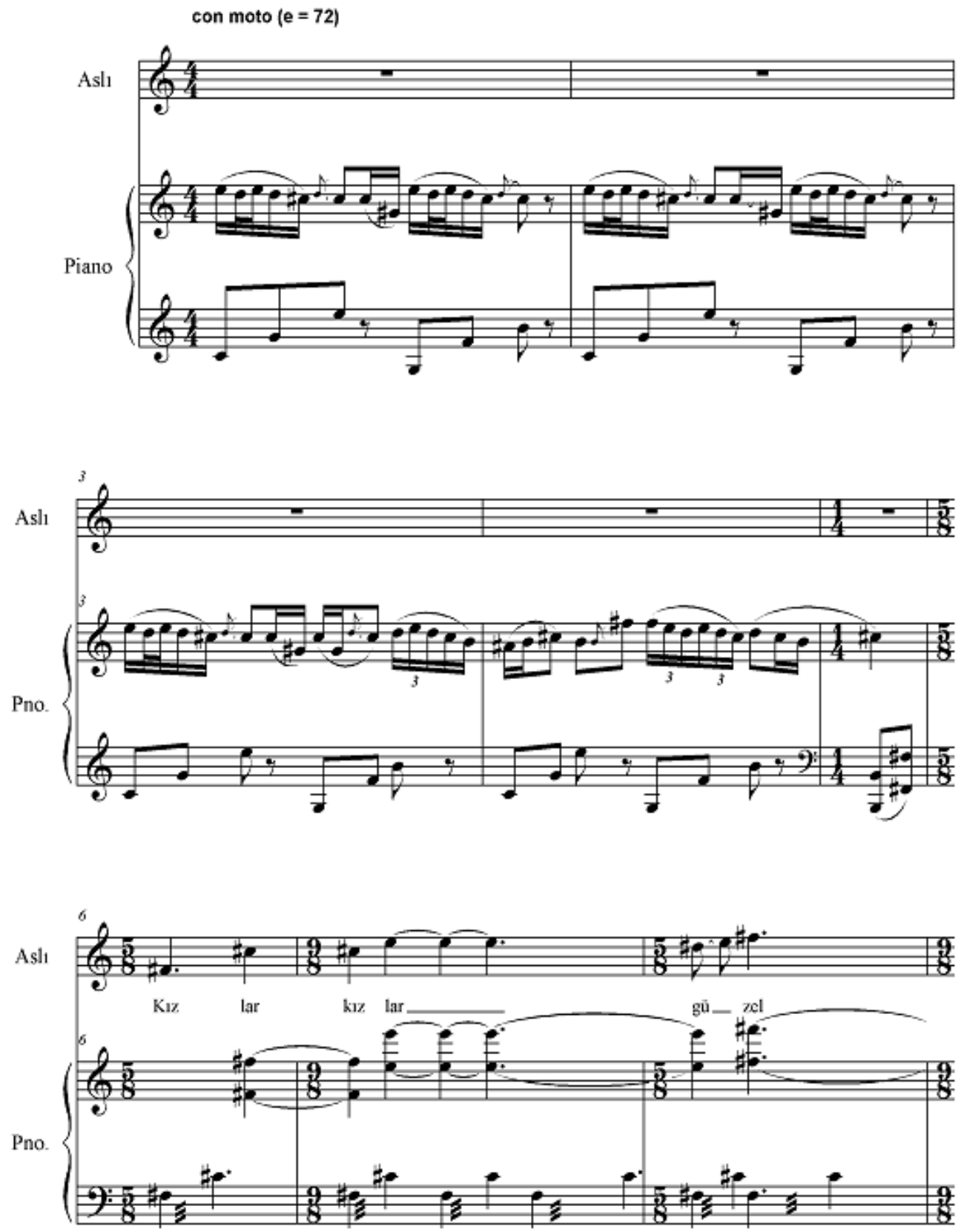

Example 1. Kerem opera, number 5 

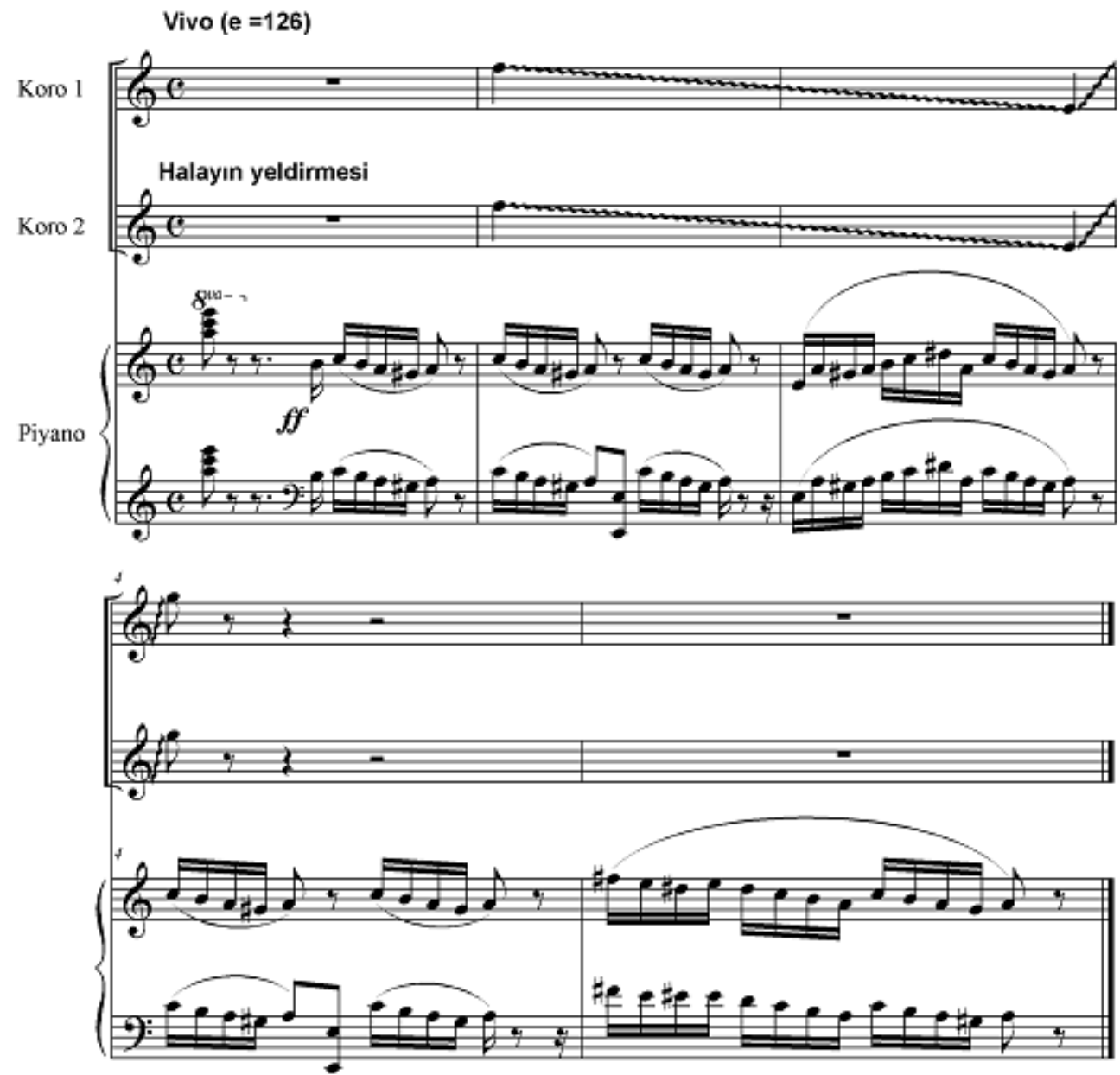

Example 2. Halay winding

On the piano, both hands move in parallel with the same melody. Although Saygun quotes from the Folk Music in the halay section, the Halar Yeldirmesi section is his composition. Numbers sixteen to seventeen are very clear throughout the episode.

Seventeen numbers come to the water of hunters. A similar scene is found in Wagner's Siegfried. After seventeen numbers and 10 verses, the use of a water motif, often met in Debussy and French music, is seen. This use proves Saygun's closeness to French music. This motif used by Saygun is an example of a Full Tone sequence (one octave from $\mathrm{C}$, the interval between notes is one tone. There are six notes, no halftone). Harmoniously, the right and left hands move opposite each other on the piano. From the nineteenth to the twentieth number, Kerem sings a folk song. Saygun benefited from the Ashug tradition here. 
Kuglas Aifumm elrafonde halka olierias.
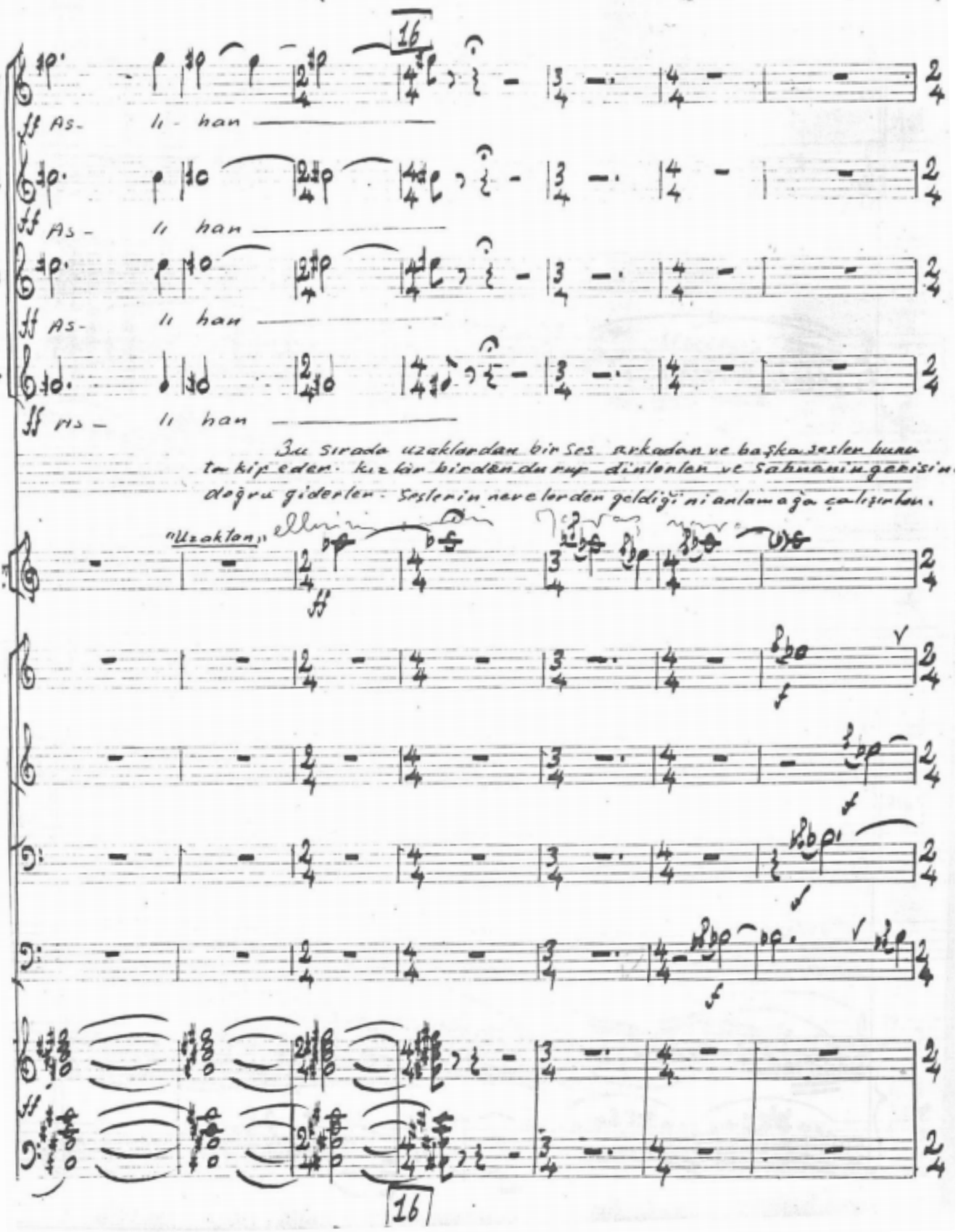

Example 3. Pentatonic sequence 

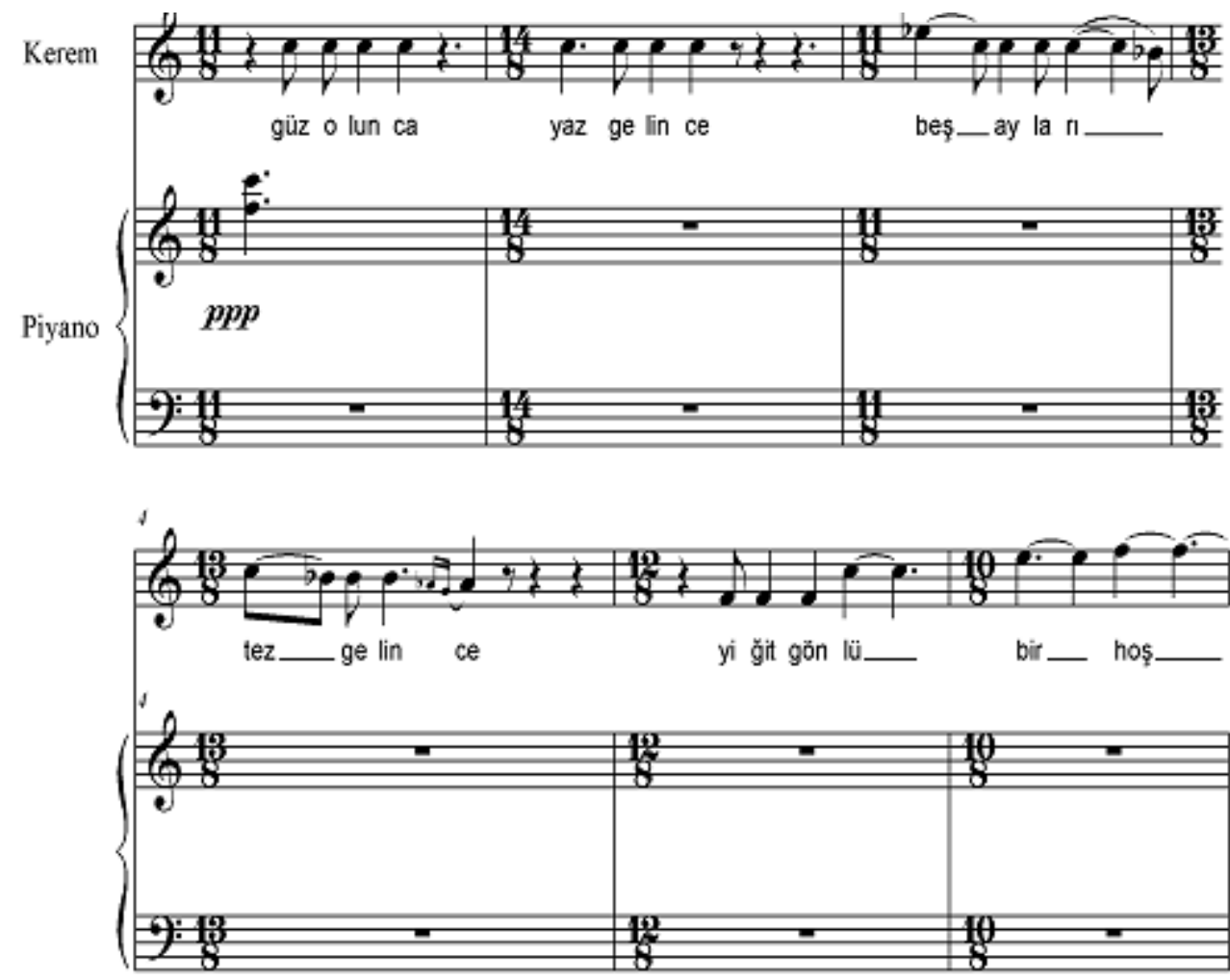

Example 4. Kerem's song

The song is based on Husseini's status on the Fa-voice. Most of the folk songs in Anatolia are based on Husseini's status. Kerem, who came to the water's edge by singing this song, sees the reflection of the water Asli. From number 26, the pentatonic sequence and tonal chords follow the full tone sequence that begins three cells before each other, creating a variable movement.

Number 32 shows a pentatonic sequence based on the sound of Re Major on the one hand and $\mathrm{F}$ on the other. While Saygun expressed this great love scene with pentatonic, the pentatonic music enriched the emotional changes with tonal harmony, as it sounded more naked.

Saygun, in number 33, built chords based on the sound of Des without using functional connections. This style of writing is also characteristic of Debussy and Impressionist composers (another feature of these harmonies is that they consist of overlapping quartets and are associated with parallel movements). Added by non-chordal sounds with septimal (seventh chords), the composer used a diatonic chord (ie, non-chromatic) chord type that was different from the sounds in the Des-dur sequence. This is a unique tonal chord style that Adnan Saygun often uses.

We hear the double chords again, 14 measures before the 40th number. The piano also used G-shaped chords on the right and Fis-chords on the left. The section from 
the first act to the third scene is also performed by Kerem and his parents, which is one of the real parts of the play. The use of the chords and sequences I have given above continues in a similar way throughout the work.

Kerem's performance in the third scene of the second part is completely different from the dramatic content of the music. The orchestral music of this episode is the background of a caravan slowly approaching and moving away. Here the folk song, sung from time to time by the passengers with the unchanging repetition of the caravan choir, continues in parallel with the hesitant flow of the orchestral background. Thus, the song of the orchestra, choir and passengers creates a pedal character in motion. The Kerem bee, which must be read on such a pedal in completely free air, is no different from the psalmody, a reminder of the primitive times (a way of reciting hymns in a monotonous mode). Thus, it allows the emergence of a character approaching the Anatolian ceremonial melodies (as a requiem).

The general structure of the third act is dominated by the fret-tonal connection. It creates a divine atmosphere in this work. At the beginning of the curtain, the first dimension begins with an arpeggio-shaped modal march of a full quadruple tetrachord, and the second dimension descends with tonal use.

Although a completely tonal texture is used in two hundred and twenty-nine, some sounds contradict the structure of the B dur gamma.

Two measures after the number 233 begin polytonal writing. In a tonal substructure, small scales and highlights are seen to be used together. The use of this modal tone allows us to hear the colours that create the mystic aura.

Then measures after the number 233 , the modal-magam structure is seen in the chorus again. This effect is $F$, and the sound $G$ was supposed to be gis, but here $\mathrm{G}$ is used alone (left singular), which adds a modal feature to this structure. The piano part is in tonal texture. Again, Modal is a repetition of tonal use.

The episode where the lovers are on stage begins with the number two hundred and fifty-three. The second, Ashig's folk song, which begins with two hundred and sixtyone, has the folklore features of the Aegean Region. The folk song, which continues modally in two hundred and sixty-three, continues in three-fourths with Makam Nikriz and ends with Segah. This creates a sense of Zeybek variations.

Kerem's aria in the first scene of the last act still has the style of the psalms. However this aria becomes only a psalmody atmosphere in a psalmody atmosphere divided by the rhythmic rhythms of the percussion instruments (occasionally the musician continues his rhythmic flow as he pauses) as in terms of broad line melody structure. The caravan scene in the third scene of the second part is different from the aria in that it is written.

Saygun uses the phrase that this aria carries the air of "Bozlak eruption". Soprano solo recitative prepares for the final. At the end of the work, the hymn, sung in chorus number three hundred and thirty-one, begins with the status of Segah from the sound of $F$, continues as Segah, and ends with a tonic trio with a transition to the tonality $B$, which is an expression of attainment.

In the real flow of opera, the music that reflects the differences between spiritual experiences becomes an abstract atmosphere in its place, but despite everything, only a modal atmosphere dominates almost the whole work. It is necessary to use a spatial structure to show the unique colour, smell, and character of Anatolia. For this 
reason, the writing technique created by the composer to explain the different moods that Kerem experienced during the development of the subject was emphasized in the music due to the characteristics of spiritual change.

The premiere of the opera Kerem was held on March 22, 1953, on the stage of the Ankara State Theater. At the performance ceremony at the State Theater, the composer himself acted as the main conductor. The role of Kerem was played by Aydin Gun, and the role of Asli was performed by Ayhan Alnar (Kolçak, 2005, p. 90).

\section{Conclusions}

As a result, Saygun's Kerem opera is one of the different applications of the Sufi philosophy that brings peace. The suffering of the truth-seeker heralds the coming of the truth. The way of light is the way of God so that people may be free from pain and oppression and all evil may be forgotten. To show the unique color, smell, and character of Anatolia, the life and customs of the people, Saygun used a lad-maqam structure. For this reason, the writing technique created by the composer to explain the different moods that Kerem experienced during the development of the subject was emphasized in the music due to the characteristics of spiritual change. One of the most important features of Kerem's opera is his mastery of folklore, music, and oral values. Folklore is neither a model nor a repertoire to be quoted. In Kerem's opera, every element of folklore and tradition, a universal element, has been elaborated and recreated with great skill and enthusiasm following the theories and rules of world music. Living traditions; can be updated at any time. Societies that have lost their ability to regenerate will have neither traditional art nor folklore. We have witnessed the analysis of how enthusiastically and enthusiastically the Kerem opera works on national values in every dimension of the composer.

\section{References}

Akdoğan, B. (2009). Mevlevilik ve Musiki [Mevlevi and Music]. Rağbet Yayınlar [in Turkish]. Altar, J. M. (2001). Opera Tarihi [History of Opera]. Pan Yayıncılık [in Turkish].

Gönen, G. B. (2008). Çağdaş Türk Opera Sanatının Içinde Ahmed Adnan Saygun Operalarının Dramaturjik Açıdan Incelenmesi [A Dramaturgical Analysis of Ahmed Adnan Saygun's Operas in Contemporary Turkish Opera Art] [Master's Thesis]. Fine Arts Institute, Ankara [in Turkish]. Gun, A. (1991). Operada Dil Sorunu ve Kerem Üstüne Düşünceler [Language Problem in Opera and

Thoughts on Grace] [Booklet]. İstanbul Devlet Opera ve Balesi [in Turkish].

Kolçak, O. (2005). Ahmet Adnan Saygun. Kastaş Yayınları [in Turkish].

Kürkçüoğlu, S. (2006). A. Adnan Saygun ve Kerem Opera [A. Adnan Saygun and Kerem opera] [Master's Thesis]. Mimar Sinan Fine Arts University, Istanbul [in Turkish].

Refığ, G. (2012). Özsoy Operasi - Atatürk ve Adnan Saygun [Özsoy Opera - Atatürk and Adnan Saygun]. Boyut Yayın Grubu [in Turkish].

Tuzlu, A. (2019). Türk Operasını Oluşum Süreci ve Ahmet Adnan Saygun'un Özsoy Operasının Analizi [The Formation Process of Turkish Opera and Analysis of Ahmet Adnan Saygun's Özsoy Opera] [Master's Thesis]. Hacettepe University, Ankara [in Turkish]. 
Voronova, T. (2020). Praktychne Znachennia Slovesnoi Skladovoi Opery v Konteksti Rozvytku Rezhyserskoho Teatru XX-XXI stolit [Practical Significance of the Opera's Verbal Component in the Context Regarding the Development of Director's Theatre in the 20-21st Centuries]. Visnyk Kyivskoho Natsionalnoho Universytetu Kultury i Mystetstv. Seriia: Muzychne Mystetstvo [Bulletin of Kyiv National University of Culture and Arts. Series in Musical Art], 3(2), 146-155. https://doi.org/10.31866/2616-7581.3.2.2020.219160 [in Ukrainian].

\title{
АНАЛІЗ ОПЕРИ АХМЕТА АДНАНА САЙГУНА «КЕРЕМ»
}

\author{
Айсель Асадова
}

докторант; ORCID: 0000-0001-8183-3191; e-mail: asadova.aysel.1@mail.ru

Бакинська музична академія імені Узеїра Гаджибейлі, Баку, Азербайджан

\section{Анотація}

У статті аналізується музична мова опери Ахмета Аднана Сайгуна «Керем». Ахмет Аднан Сайгун народився в період Османської імперії і жив в новоствореній Турецькій Республіці, був одним із засновників турецької школи композиторства та «Турецької п'ятірки». Композитор приділяв значну увагу народній творчості, національним цінностям, тому у його творах завжди присутня народна музика і фольклор.

Мета дослідження - аналіз суфійських мотивів в сценах опери. Переважно приділяється увага музичній драматургії і гармонійним аспектам опери, які безпосередньо відображають турецький фольклор і музичну культуру загалом.

Методологія дослідження полягає у розв'язанні науково-теоретичної проблеми Застосовано ряд теоретичних і аналітичних методів, що виділяють принцип використання літературного тексту в музичних сценах, які містять вислови, що відображають в суфізмі «возз'єднання з Творцем». При пошуку інформації використовувалися методи аксіологічної концепції культури, що дозволило виділити характерні ознаки турецької музики.

Наукова новизна дослідження. Вперше розглянуто відображення релігійних особливостей на основі народної музики, зокрема на основі ладової структури і макамів, аналізі містичних мотивів опери, в поєднанні з сучасними музичними засобами.

Висновки. Опера Ахмета Аднана Сайгуна «Керем»- одне з рідкісних витворів, що засноване на суфійській філософії. Відзначено чітке відображення основної думки суфійської філософії в "Керем», згідно з якою страждання шукача істини знаменуються поверненням до неї. Шлях світла - це шлях Аллаха. Композитор, щоб показати унікальний колорит і характер Анатолії, побут і звичаї людей, використовував характерну для турецької музики ладову та ритмічну структуру. В результаті дослідження ми бачимо, як в «Керем» автор з ентузіазмом і захопленням працює над національними цінностями в усіх аспектах опери.

Ключові слова: опера; модальна структура; містика; політональність; основи народної музики 


\section{АНАЛИЗ ОПЕРЫ АХМЕТА АДНАНА САЙГУНА «КЕРЕМ»}

\section{Айсель Асадова}

докторант; ORCID: 0000-0001-8183-3191; e-mail: asadova.aysel.1@mail.ru

Бакинская музыкальная академия имени Узеира Гаджибейли, Баку, Азербайджан

\section{Аннотация}

В статье анализируется музыкальный язык оперы Ахмета Аднана Сайгуна «Керем». Ахмет Аднан Сайгун родился в период Османской империи и жил в Турецкой Республике, был одним из основателей турецкой композиторской школы и «Турецкой пятерки». Композитор уделял большое внимание народному творчеству, национальным ценностям, поэтому в его произведениях всегда присутствует народная музыка и фольклор.

Цель исследования - анализ суфийских мотивов в сценах оперы. Преимущественно уделяется внимание музыкальной драматургии и гармоничным аспектам оперы, которые напрямую отражают турецкий фольклор и музыкальную культуру в целом.

Методология исследования заключается В решении научно-теоретической проблемы. Применен ряд теоретических и аналитических методов, выделяющих принцип использования литературного текста в музыкальных сценах, которые содержат фразы, отражающие в суфизме «воссоединение с Творцом». При поиске информации использовались методы аксиологической концепции культуры, что позволило выделить характерные признаки турецкой музыки.

Научная новизна исследования. Впервые рассмотрено отражение религиозных особенностей на основе народной музыки, в частности на основе ладовых строений и макамов, анализе мистических мотивов оперы, в сочетании с современными музыкальными приемами.

Выводы. Опера Ахмета Аднана Сайгуна «Керем» - одно из редких произведений, основанных на суфийской философии. Отмечено четкое отражение основной мысли суфийской философии в «Керем», согласно которой страдания искателя истины знаменуются возвращением к ней. Путь света - это путь Аллаха. Композитор, чтобы показать уникальный колорит и характер Анатолии, быт и обычаи людей, использовал характерную турецкой музыке ладовую и ритмическую структуру. В результате исследования мы видим, как в «Керем» автор с энтузиазмом и азартом работает над национальными ценностями во всех аспектах оперы.

Ключевые слова: опера; модальная структура; мистика; политональность; основы народной музыки 